\title{
De zorg ontketend? in ketens?
}

Citation for published version (APA):

Pop, P. (2000). De zorg ontketend? in ketens? Afscheidsrede van Dr. P. Pop. Universiteit Maastricht. https://doi.org/10.26481/spe.20000101pp

Document status and date:

Published: 01/01/2000

DOI:

10.26481/spe.20000101pp

Document Version:

Publisher's PDF, also known as Version of record

\section{Please check the document version of this publication:}

- A submitted manuscript is the version of the article upon submission and before peer-review. There can be important differences between the submitted version and the official published version of record.

People interested in the research are advised to contact the author for the final version of the publication, or visit the DOI to the publisher's website.

- The final author version and the galley proof are versions of the publication after peer review.

- The final published version features the final layout of the paper including the volume, issue and page numbers.

Link to publication

\footnotetext{
General rights rights.

- You may freely distribute the URL identifying the publication in the public portal. please follow below link for the End User Agreement:

www.umlib.nl/taverne-license

Take down policy

If you believe that this document breaches copyright please contact us at:

repository@maastrichtuniversity.nl

providing details and we will investigate your claim.
}

Copyright and moral rights for the publications made accessible in the public portal are retained by the authors and/or other copyright owners and it is a condition of accessing publications that users recognise and abide by the legal requirements associated with these

- Users may download and print one copy of any publication from the public portal for the purpose of private study or research.

- You may not further distribute the material or use it for any profit-making activity or commercial gain

If the publication is distributed under the terms of Article $25 \mathrm{fa}$ of the Dutch Copyright Act, indicated by the "Taverne" license above, 
De zorg ontketend? in ketens?

Proff. Dr P. Pop 

Transmurale zorg staat in de gezondheidszorg in Nederland wolop in de belangstelling. Deze vorm van zorg wordt bepleit door de Stuurgroep Toekomstscienario"s Gezondheidszorg (1988, 1992), de Mationale Ziekenhuisraad (1990), de Gezondheidsraad (1991) en de Commissio modemisering curatieve zorg (1994). Hel doel wan transmurale zorg is tweeledig: vergroten van de doelmatigheid van zorg en het realisenen van zorg op maat.

In de gezondheidszorg zijn de laatste jaren veranderingen aan de orde van de dag. Ideeën gedachten en planen die ten grondslag liggen aan deze veranderingen vloeien voort uit een toename wan de zorgvraag (meer techmische mogelijkheden, vergrijzing van de bevolking), een herschiklking wan het zorgaanbod (met een doorbrak van de muren tussen eerste en tweede echelon), verandering in het verzekeringsstelsel (grotere verantwoondelijkheid voor de verzekeraar en meer vraag om "value for money'), een sociaal-economisch en politiek klimaat: met aandacht woor de patiënt (zorg op maat) en doelmatigheid van de zorg.

Aan principes van transmurale zorg en managed care ontleende instrumenten zijn bruikbaar om gewenste veranderingen in de zorg gestalte te geven. Barrieres op de weg naar aan de eisen van 2000 beantwoordende zorg zijn ruinschoots anwezig in de zin wan samenwerkings- en organisatieproblemen, belangen-tegenstellingen, beperkte deskundigheid, kennis en vaardigheden, tekort aan menskracht en tinanciering.

Transmurale zorg wordt door de Nationale Rad voor de Volksgezondheid (NRV) en het College voor Ziekenhuisvoorzieningen (CVZ) gedefinieerd als vommen van zorg die, toegesneden op de behoefte van de patiènt, verleend worden op basis van afspraken over samenwerking, afstemming en regie tussen generalistische en specialistische zorgverleners, waarbij sprake is van een gemeenschappelijk gedragen verantwoordelijkheid met expliciete deelverantwoordelijkhedlen.

De Stichting Ziekenhuisverplaatste Zorg ( $S Z v Z$ ) heeft het model wan de brug geïntroduceerd. Vier pijlers vertegenwoordigen de transmurale zorg. Gezamenlijk representeren de pijlers van deze brug een continuilm van zorg, waarbij optimaal gebruik gemaakt wordt van de mogelijkheden van eerste en tweede lijn. De eerste pijler symboliseert door het ziekenhuis geboden specialistisch-verpleegkundige zorg en medisch-specialistische behandeling thuis, waarbij de regiefunctie bij het ziekenhuis ligt. De tweede pijler vertegenwoordigt door het ziekenhuis en de eerste lijn gezamenlijk gegeven zorg, waarbij er sprake is van gemeenschappelijke taken en verantwoordelijkheden. Bij de derde pijler wordt door de eerste lijn verleende zorg ondersteund door het ziekenhuis; de verantwoordelijkheid ligg bij de eerste lijn, terwijl het ziekenhuis een consultatiefunctie heef. De vierde pijler wordt in het model van de brug gezien als door de eerste lijn geboden zorg en behandeling, waarbij het ziekenhuis slechts exn overdrachtsfunctie heef. In een door Assmann gernodificeerd brugmodel wordt een regional zorgnetwerk werbeeld. De eerste lijn wormt én oever, watr het kemproduct extramurale generalistische zorg wordt geleverd.

De eerste lijn levert woor de opbouw van transmurale zorg de 'halfproducten' generalistische zorg en extramurale voorzieningen in de thisomgeving van de patient. Het ziekenthuis vormt de andere oever waar het kemproduct intramurale specialistische zorg geleverd wordt. De bweede lijn levert voor de opbouw van transmurale zorg do "halfproducten" spectalistische zorg en intramurale woorzieningen. In de metaloor van de brug kan transmurale zorg beschouwd worden als de worm van zorg tussen de twee oevers in. Zorg op maat wordt geleverd door integratie van de genoemde halfproducten. De tuien (kabels) zijn producten van de gezamenlijke zorg door multidisciplinaire teams. 
Het brugdek wordi gevornd door een medisch coördinerend centrum (zoals dit functioneen in Amersfoon, Helmond en Matricht), dat als meutraal institwut in een regionaal zorgnetwerk als primaire doelstelling heeft de kwaliteit van de zorg te optimaliseren door verbetering van de samenwerking en communicatie lussen exte en weede hin. Een centrale pijler in dit model symboliseert de Sturgroep van het regionale zorgnetwerk. In deze Sturgroep zijn de diverse belangengroepen en organisaties die eev belangrijk asndeel levenen aan het zorgnetwerk. (zorgverleners; zorgverzekeraars, overheid en patientenorganisaties) vertegenwoordigd.

\section{Voorgeschiedenis:}

- In 1979 starte op verzoek van het Ministerie van Volksgezondheid en Milieuhygiene in Maastricht in het ziekenhuis St Amadal het experiment Dragnositisch Centrum Maastricht. (DCM) met als doelstellingen:

- Bevordering van doeltrefend en doelmatig gebruik wan de diagnostische voorzieningen van het ziekenhuis door huisartsen.

- Verbetering van de sanemwerking tussen huisarts en specialist.

- Na een succesvol experiment vond op verzoek van de huisartsen continuering van het DCM platats in de vorm van de Stichting Diagnostisch Coordinarend Centrum (DCC). Uitbreiding van doelstellingen (onderzoek en onderwijs) en activiteiten vond plaats.

- In 1994 verzocht de Raad van Bestuur (RvB) van het academisch ziekenhuis Mazstrichi: (azM) aan het DCC structurering en uitbouw van transmuralle activiteiten op zich te nemen. Een Stuurgroep Transmurale Zorg (STZ), met vertegenwoordiging wan de zorgverleners in de regio Heuvelland wordt opgericht met als hoofddoelstelling "het stimuleren van en mede vorm geven aan projectactiviteiten op het gebied wan de transmurale zorg, met name waar deze de patientenzorg betreffen'. Het DCC nieuwe stijl kreeg in de loop van 1996 de nam van "Transmuraal \& Diagnostisch Centrum' (T\&DC).

- In 1995 werd door de besturen wan de drie diagnostische centra (Amersfoort, Helmond en Masstricht) de Federatie Medisch Coördinerende Centra (FMCC) opgericht. De federatie stelt zich onder andere ten doel ruimer verbreiding te geven aan de in de bestaande centra ontwikkelde ideeën en activiteiten. Huidige activiteiten van de federatie zijn gericht op het verkrijgen wan erkenning van MCC's door de overheid en daarmee op het verkrijgen van een structurele financiering. Voorts is het streven de $\mathrm{MCC}$ s te laten fungeren als uitwoerend orgaan woor de coördinatie van een regional zorgnetwerk.

\section{Doelstellimgen en activiteitem}

De dowstellingen wan het T\&DC kumen als volgt worden verwoord:

Doelstelling 1: Het verzorgen en analyseren van door de huisarts in het ziekenthis aangevrangde diagnostische onderzoeken en consultatieve advisering; het opstellen van werkafspraken en protocollen. Het verbeteren van de relatie en communicatie tussen huisarts en specialist.

Doelstelling 2: Het bevorderen en uitwoeren van activiteiten gericht op de onwwikkeling van transmurale gezondheidszorg alsmede het fungeren als central coördinatiepunt woor transmurale zorgactiwiteiten.

Doelstelling 3: Het stimuleren, initiëren en mede witvoeren van wetenschappelijk onderzoek gericht op vragstellingen betreffende de relatie eerstetweedelijnsgezondheidszorg alsmede transmurale zorg. Het geven van onderwijs met behulp van gegevens, voortkontend uit analyses van diverse (transmurale) zorg- en onderzoekactiviteiten van het T\&DC. 
Aan deze doelstellingen ontleende activiteiten werden op versehillendie momentes ontwikkeld. Aanwankehjk stonden projecten ter ondersteuning van de huisarts centraal. later werden transmumale projecten ontwikkeld ter oplossing van structurele problemen van het atM.

\section{Projecten ter ondersteuning van de huisartsen}

Aan het takenpakket van de huisarts worden met name het laatste decennim steeds meer taken toegevoegd: meer zorg voor chronisch zieken, thuszorg, meer alaudacht woor oogheelkunde, spoedhulp: waar is de huisarts?, preventie door de huisarts, kleine chirurgie in de huisartspraktijk, betere voorlichting an de patient enz. Het is duidelijk dat de individurele huisarts met al deze taken kan toevoegen an het reeds witgebreide takenpakket. Prioriteiten dienen te worden gesteld; bij de uitwoering van een aantal taken moet ondersteuning worden gegeven. Gedachtemwisseling met betrokkenen heef in het T\&DC uitvoerig platagevonder. Ter ondersteuning van de huisarisen werden projecten ontwikkeld op grond van de volgende uitgangspunten:

- De huisarts dient zich meer te bekwamen in txandvaardigheden voor onderzoek wan frequent in de huisartspraktijk voorkomende ziektebeelden dan zorg te dragen voor aanschaf van technische apparatuur in de huisartspraktijk.

Als project kan hier genoemd worden de persoonlijke feedback aan de huisaris betreffende 7ijn diagnostisch handelen (toctsing cm nascholing).

- De specialist dient zich meer op te stellen als consulent woor de huisarts.

Als vormen van consultatie werden ontwikkeld: de telefonische consultatie, het gezamenlikk consult in de spreekkamer van do huisarts en het gezamenlijk consult aan thet ziekbed van de patiènt thuis.

- De huisartis dient in cen aantal werkzaamheden ondersteund te worden door hiervoor speciaal opgeleide medewerkers.

Projecten werden ontwikkeld in de zin van infuustherapie in de thuiszorg en continulteit van zorg voor patiënten met chronische aandoeningen in een stabiele fase door mel name hiervoor opgeleide transmuraal vempleegkundigen.

- De communicatie en samerwerking tussen huisarts en specialist dient te worden verbeterd via onderlinge afspraken over organisatorische en wakinhoudelijke zaken.

In periodieke bijeenkomsten van vertegenwoordigers van huisartsgroepen en leden wan telkens één specialistische wakgroep worden bedoelde afspraken gemaakt.

- De huisarts dient voor uitwoering wan taken op het terrein wan de gezondlheidszorg ondersteund te worden door gebnik van hiervoor ontwikkelde programmatuur gekoppeld aan een huisartsinformatiesysteem.

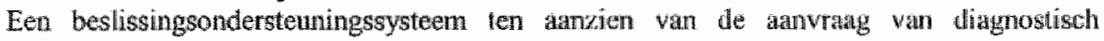
onderzoek door de lutisarts wordt ontwikkeld.

Enkele vootbealden van projecten:

- Persoonlike feedback aan dle huisarts ten anozien van diagnositisch onderzoek

In 1985 werd gestart met het geven wan feedback atan alle thustartsen betreffende de door hen via het T\&DC angevraggde diagnostiek. De doelstelling van doec reedback is het beworderen van een meer rationeel anwraaggedrag door huisartsen. Deze feedback vindt plaats op basis van o.2. met de huisartsen gemaakte werkalspraken (indicatios voor aanvraag van tests, richtlinen voor diagnostiek bij omschreven klachten/symptomen/ ziektebeelden) en op basis van prineipes van medische besliskunde. 
In de penode 1985 - 1990 werden voomamelij adviezen gegewen ower diagnostisch onderzod ten aanzien wan bloedcheme, hemalologie, serologie/virologie, faecesuraneonderzoek en bactenollogie. In en wetenschappelijk onderzoek (proefsehrift Winkens 1994) werden in de periode 1990 - 1992 ook adviezen gegeven over beeldvormende diaginostiek, ECG-aanvragen en PA onderzoek. Vooratgande aan de feedback was ar in de periode 1979 - 1985 conform de landelijke lendens een stiging van bot aantal door huisartsen angevragide onderzoken te zien, damatherd onder invloed van de feodback een duidelike daling van het antal onderzoeken wastgesteld. Berekend op basis wan CorG-iarieven wan diverse onderzoeken werd al in 1991 vastgesteld, dat er sprake was wan een kostenbesparing van meer dan 2.000 .000 gullden per jaar.

Tabel 1 toont de door de huisartsen in azM adngevragde diagnostische werrichtingen in de pentode 1982-1998.

Na een dudelijke afname van deze aantallen verrichtingen vanaf hel moment 1985 dat gestructureerde feedback workt gegeven laat de tabel zien dat er vanaf 1996 cen duidelijk foename is van met name aanvragen khnische chemic en in mindere mate wan asmvragen hematologie, immunologid/strologie/virologic, urine/faeces en bacteriologie. Desgewragd geven de huisartsen aar dat deze toename van diagnostische aanvagen het gevolg is wan een toenemende verschuiving wan zorg van de tweede naar de eerste lijn. Analyse op het niveau van individuele tests laat zien dat er ten aanzien wan de klinische chemie een duidelijke toename is van tesits betreffende de velstofwisseling (chollesterol e.d.) en van de aranvragen bloedsuiker, HbA Ic, PSA en schildklierfunctietests. Van de totale toename aan klinisch chemische tests in 1998 komt $23.4 \%$ voor rekening van de toename van de tests van de vetstofwisseling. De combinatie van de vier tests van de vetstofirisseling bedraagt $25.7 \%$ van alle door hulisartsen aangevraagd kinische chemische tests. Veel aandacht in do media voor "het cholesterol" en nascholing betreffende risicofectoren woor han- en vaatziekten liggen waarschijnlijk ten grondslag an de toename van deze bepalingen. Tenugverwizing door specialisten van patıenten met een stabiele diabetes mellitus type II en het volgen van aanbevelingen in de NHG-standaarden betreffende controle van patienten met een diabetes mellitus zallem de toename van de aanvragen bloedsuiker en HoA lo veroorzaakt hebben.

Tabel 2 laat zien dat ten aanzien van vergelijkbare pakketten aanvragen laboratoriumtests en röntgen functie-onderzoeken de Maastrichtse huisartsen in 1997 duidelik minder tests per thuisarts per jaar aanvragen cain huisartsen in de vijf andere genoemde regio's.

Tabel 2. Aanvragen diagnostisch onderzoek per huisarts in diverse regio's in 1997

\begin{tabular}{lcc} 
Regio & $\begin{array}{c}\text { Gem. lab } \\
\text { anvragen }\end{array}$ & $\begin{array}{c}\text { Gem. röngent } \\
\text { functie aanvragen }\end{array}$ \\
\hline Helmond $(n=62 ; 100 \%)$ & $1273 \pm 652$ & $121 \pm 88$ \\
Nijmegen $(n=57 ; 50 \%)$ & $1086 \pm 468$ & $94 \pm 78$ \\
Sittard $(n=48 ; 50 \%)$ & $2251 \pm 1254$ & $161 \pm 90$ \\
Bennekom $(n=41 ; 50 \%)$ & $1.409 \pm 614$ & $110 \pm 62$ \\
Veldhoven $(n=54 ; 90 \%)$ & $1955 \pm 817$ & $145 \pm 80$ \\
Alle regio $s(n=262)$ & $1573 \pm 903$ & $126 \pm 84$ \\
Maastricht $(n=87 ; 100 \%)$ & 945 & 91 \\
\hline
\end{tabular}

WOK.W. Verstappen 


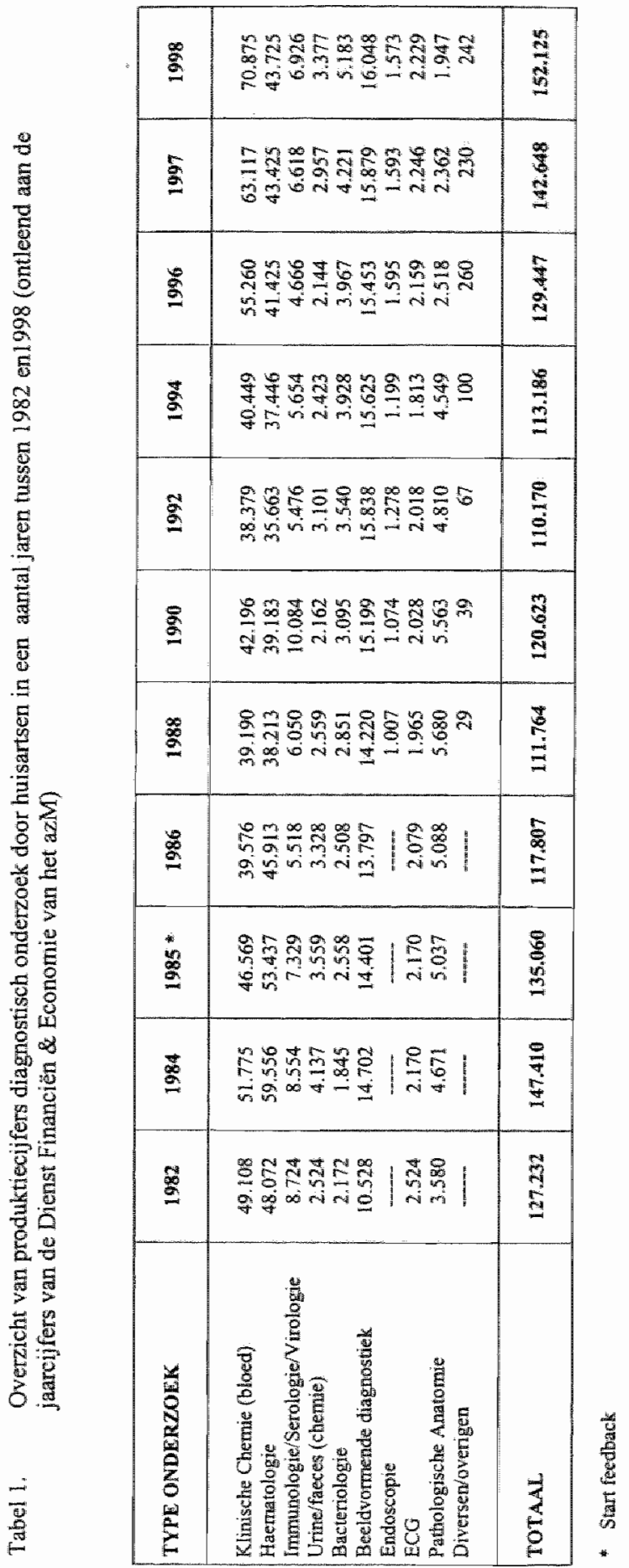


In 1998 word in samenwerking met de vakgroep Medische Informatica gestan met en project 'computerreminders over diagriostiek'. Nagegaan word of een geawtomatiseerd besissingsondersteunend systeem de rationaliteit van hert diagnostisch aanvraggedrag wan huisartisen kan verbeteren, zoals dil het geval is via de schnftelik gegeven feedback.

In ext landelijk overleg van het Nederlands Huisarts Genootschap (NHG), Nederlandse Vereniging Klnische Chemie (NVKC), Stichting Artsenlaboratoria Nederland (SAN) en T\&DC vinden discussies plaats over uiteenlopende mogelijkheden om het diagnostisch aanwaaggedrag van huisartsen te verbeteren.

\section{- Gezamenlifk consult thuisarts-spectalist in de spreekkamer van de huisartis}

De doelstelling van dit consult is een toename wan kennis en technische vaardigheden van de huisarts in onderzoek van patienten met frequent in de huisartspiaktijk voorkomende problemen. Wetenschappeljk onderzoek werd verricht naar de resultaten van het gezamenlijk consult huisarts-orthopedisch chinurg. Uit dit onderzoek (proefschrift Viethout 1994) komt naar voren, dat gezamenlijke consultspreekuren voor huisarts en orthopedisch chirurg organisatonsch goed uitwoerbaar zijn; dat gezamenlijke consult-spreekuren in belangrijke mate bijdragen aan een gerichter en doelmatiger verwijsbeleid van de huisants; dat het patientenaanbod voor dit consult na 1.5 jaar deelname daalt als gevolg van optredende nascholingseffecten; dat de kostendaling als gevolg wan de afname van het aantal verwijzingen en verrichtingen groter is dan de kosten verbonden aan het gezamenlijk consult (kostenbesparing per huisartspraktijk in het eerste jaar van deelname: $16.000,-)$.

Onderzoek naar de effecten van het gezamenlijk consult huisarts cardioloog werd verricht in de periode $1994-1997$ (proefschrif Vlek wolgt in 2000). Het aantal verwijzingen nar de tweede lijn bleck in de interventiegroep significant lager dan in de controlegroep. De huisartsen gaven in een semigestructureerd interview aan het gezamenlijk consult te zien als een belangrijke nascholingsbron. Door middel van een kennistoets kon een positief nascholingseffect niet bevestigd worden.

Het gezamenlijk consult huisarts-dermatoloog startte in 1997 . In dit project is er tevens sprake van het teleconsult dermatologie, waarbij vanuit de huisartspraktijk dermatologische beelden via de computer verzonden worden aan de dermatoloog. De dermatoloog is behulpzaam bij het stellen van de diagnose en geef beleidsmatige adviezen.

Met het gezamenlijk consult huisarts-reumatoloog werd eveneens in 1997 een begin gemaakt. Het betreft hier niet alleen nieuwe patienten waarbij de huisarts een gezamenlijk consult geïndiceerd acht in plats van een verwijzing, doch ook patiënten met een slabiele reumatoide artritis die vanuit de polikliniek terugverwezen kumnen worden naar de huisarts.

\section{- Telefonische cousultatie huisarts-specialist}

De telefonische consuliatie is een gestructureerd overleg wan huisarts en specialist warin problemen van diverse ard (diagnostisch, therapeutisch enz) kunnen worden besproken. Op cen tevoren vastgesteld ijdstip vind dit overleg plaats; relevante laboratorium uitslagen en documenten zoals $\mathrm{ECG}$ en rö́ngenfoto's zijn awwezig. Verslaglegging (bestemd voor huisarts, consultatiegevend specialst en evaluatiedoeleinden) vindt plats op een hiervoor ontwomen formulier. Uit een analyse van \pm 700 door de intenist gegeven consultaties blykk, dat $85 \%$ van de besproken patiënten onder belaandeling/ controle van de huisarts kan bliven; in $15 \%$ wordt door de specialist yerwizing nar polikhniek of kliniek geadviseerd. De telefonische consultatie blijkt in een groot aantal gevallen een goed altematief te zijn voor en poliklinische verwijzing. 


\section{Transmuralle projecten}

Het azM heef als enige ziekentuis in de regio functies als centrumciekenhuis (regronale zorg) en academisch ziekenhuis (topklinische/topreferente zorg en onderzoklonderwijs). Door te grote aantallen patiênten ten aanzien van de regionale zorg waarvoor onvoldoende budget aanwezig is, bestaat er cen spanningsveld tussen de fincties als centrum- en academisch ziekenhuris. Overbezetting wan bestaande capaciteit leidt in de patientitenzorg tot lange doorstroontijden met name in de polikliniek Dit blijkt een landelijk probleem te ajjn.

Mediator meldde medio 1998 dat er een grootschalig project "verkorting doorstroomtijden" gestart werd, waarbij in acht ziekenhwizen in Nederland aangetoond moet worden dat diagnostiek en behandeling wan omschrewen klachten en ziektebeelden sneller kan plaatsvinden - dan tot nu toe veelal het geval is. VWS heeft wia Zorgonderzoek Nederland (ZON) gelden woor het project ter beschikking gesteld. Acht verschillende zorgiprocessen zijn geselecteend: letsel/bew egingsapparaatmeniscus, nug/nek, hemia nuclei pulposi, hartrevalidatie, diabetische voet, onbegrepen klachten, moeheid en manmacarcinoom. Zestien teams voeren in acht ziekenhuizen dit project uit, waarbij twee soortgelijke zorgprocessen in twree ziekenhüzen worden herontworpen. Nagegaan wordt in welke mate een betere afstemming bijdraagt axm het verkorten van de doorstroomtijden van de geselecteerde zorgprocessen en daarbij tevens de effecten op het bekorten wan de wachttijden en het verbeteren van de kwaliteit en doelmatigheid. De: opzet is een veranderd traject gebaseerd op de methodiek van Business Process Redesign (BPR). Deze procesherontwerpprojecten zijn per definitie multidisciplinair. Zorgprocessen worden in hun totaliteit en in hum samenhang geanalysererd en herontworpen. Daarbij wordt het hele verloop van een zorgproces van begin tot eind in kaart gebrachit en geanalyseerd.

Ongewwiffeld zal het mogelijk zijn doorstroomtijden bü deze zorgprocessen te verkorten. Hierbij kan de wrang gesteld worden of verbetering door middel wan herontwerp wan een relatief klein aantal, sterk afgebakende zorgpiocessen ten koste gaat van andere, moeilikker af te bakenen en te stroomlinen zorgprocessen. Er zall dan wellicht sprake zijn van nog langere wachtijden voor deze patienten, wanneer zij aansluiten in de rij achter diegene die woortang genieten.

In Maastricht werd gekozen voor de analyse van de procesgang van patiènten door polikliniek en kliniek, waarbij structurele knelpunten gesignaleend kunnen worden. In het kader van hiervoor te geven oplossingen kan nadere prioritering plaatsvinden door een keuze te maken uil kwaliteitsprojecten op basis van factoren zoals:

- de emst van het vastgestelde knelpunt:

- de kwaliteit van de beoogde oplossing het positieve effect op andere knelpunten (de 'demonstratiewaarde");

- de praktische uitwoerbaarheid en halbaarheid van het project (niet le complex, niet te bedreigend, meetbaar, beschikbaarheid wan de gegevens);

- de mogelijkhed tot implementatie en borging van do verandering, zodal daadwerkelink sprake is van een verbetering (de 'te behalen winst').

Knelpunten en verbeterprojecten kunnen als volgt worden benoemd:

Procesgang poliklinick

1. Verwijzingen

- lange wachttijden nieuwe patiènten (poliklinische triage)

- veel werwijzende huisartsen (feedback huisartsen; gezamenlijk consult huisarts specialist; telefonische consultatie)

- second opinions (informatie adherentiegebied)

2. Diagnostiek (feedback over diagnostiek; poliklinische triage)

3. Terngverwijzing (chronische patienten in stabiele fase) 
1. Onterecht verblif klinick (appropriateness evaluation protocol; gezamenlijk consin geriatip)

2. Verwoegd ontslag (infus in de thuiszorg: vervroegd ontslag na totale heupprothese en knieprothere; CVA-project)

\section{- Lange wachtijden nieuwe poliklinische patienten: pollklinische triage}

Klachten wan huisantsen omtrent lange wachttjiden hebben met name betrekking op nieuwe patienten die in verband met enstige problematiek op korte termijn door de specialist zouden moeten worden gezien. De data voor eerste polikliniekbezock van nieuve patienten worden afgesproken door de administratief medewerkers, die via telefonisch contact met patienten in chronologische wolgorde vrije plaatsen in het afsprakenbestand voor niewwe patiènten opvullen. De administratief medewerkers zijn onbekend met de ernst van medische problematiek en houden hier ook bij de planning geen rekening mee.

Bij de poliklinische triage meldt de huisarts nieuwe patiënten aan via een standaard venwijsbrief per fax/post. De verwijsbrief wordt beoordeeld door een hiervoor aangewezen specialist die op basis van de gegevens van de verwijsbrief beoordeelt wanneer en door wie de patient dient te worden gezien. Bij deze beoordeling wordt rekening gehouden met wensen van huisartsen en patienten. Aar de patiẻnt wordt vervolgens schriftelijk geneld bij wellke werkgroep/specialist en warneer hel eerste polikliniekbezoek kan plaatsvinden; de huisarts ontwangt cen kopie van dit bericht. De tot duswer opgedane envaringen met dit project bij de polikliniek interne geneeskunde wallen positief uit. Een knelpunt blift het grote aantal nieuwe patienten dat vanuit de eerste lijn wordt verwezen naar de polikliniek.

\section{- Veel verwijzende huisartsen: feedback op verwijzingen}

Van nieuw verwezen patiênten naar de polikلimiek Interne Geneeskunde blijkt een redelijk hoog percentage $(30-40 \%)$ onterecht. Hierover bestat overeenstemming lussen huisartsen en internisten. Het is niet zo dat iedere huisarts met enige regelmaat ten onrechte verwijst. Er bestaan ten aanzien van dit fenomeen grote verschillen tussen de huisartsen onderling. De polikluniek Inteme Geneeskunde startte een feedbackproject omtrent de naar de polikliniek verwezen patiènten. In overleg tussen de huisarts en intemist zijn afspraken gemaakt over indicaties voor verwijzingen. Hierbij is uitgegaan van algemene richtlinnen en mer specifieke ind"caties in het kader van verwijzingen van veel voorkomende klachten/symptomen/ziektebeelden. Door de gegewens van de verwijsbrief te relateren aan gemaakte werkafspraken wordt beoordeeld of verwijzingen al dan niet terecht zija. Twee keer per jaar wordt aan de huisarts persoonlijk feedback gegeven ten aanzien van onterechte verwijzungen (beoordeeld op basis van de verwijsbrief en zonodig gegevens uit de benichtgeving van de specialist aan de huisarts). In de feedback worden eventuele alternatieven voor een poliklinische verwijzing aangegeven (telefonische consultatie, gètamenlijk consult ed. ).

Om de kennis en vaardigheden van huisartsen te verbeteren ten aamzien van veel voorkonende problemen warvoor verwijzing plaatsvindt, zijm inmiddels enkele projecten 'gezamenlijk consult' zoals reeds besproken uitgevoerd.

\section{- Second opinions: informatie addhaerentiegebied}

Vanut het adhorentiegebied is er sprake vam en toenemend aantal verwijzingen door met name hüsartsen. Vaak wordt deze verwijzing door de huisarts omschreven als een second opinhon. Bij een relatief hoog percentage patienten lijkt er hier sprake van verwijzing van patiezuten die ontevreden zijn met de poliklinische zorg in het ziekenhuis elders. 
Dexe verwijzingen uit het adtuerentiegebied worden bij alle academische ziekenhuizen op basis wan postcodenummers geboekt als topuefierentie-verwijzingen. Het zal duideljik zijn, dat een aantal van deze verwijzingen geen topreferentie-wenwijzingen ziju volgens de hiervoor geldende definitie. In polikhimieken kunnen verwijzingen mut omschneven postcodes geanalyseerd worden op de werkelijke reden van werwijaing onbegpepen. pathologie, second opimion, huisarts/patient orvevredien met zorg ziekenhuis elders, verwijzing op aandrang van patienten. Op basis van deze analyse kunnen vervolgens uitspraken worden gedaan over het al dain miet terecht zijn van deze verwijzingen. Verwolgens dient bekeken te worden of en op welke wijze actie kan worden ondentnomen. om onterechte verwijzingen vanuit het adhenentiegebied in te perken.

\section{- Overdlagnositiek: fieedback}

Wat betreft het via de poliklinieken verrichte diagnostisch onderzoek is er - gelet op gegewens als einddiagnose, grote onderlinge werschillen bij specialisten in aamvatag wan diagnostiek e.d. - vaak sprake van overdiagnostiek. Dit kan diverse redenen hebben: onvoldoende aandacht voor anamnese/lichamelijk onderzoek, onzekerheid var de specialist (assistent in opleiding), te academische instelling (uitsluiten zeldzame ziektebeelden), defensief handelen, aandrang wan patienten anz. De gevolgen wan overdiagnostiek zijn diwers: somatisering van patienten, loenemende kosten voor de gezondheidszorg met overschrijding van budgetten, verlenging van de doorstroomtijd. Reeds besproken ervaringen wanuit het T\&DC met feedback over de diagnostiek aan de huisartsen (via anvullende diagnostiek met diagnostische faciliteiten van het ziekenhuis) op basis van werkafspraken/principes van medische besliskunde leren dat deze persoonlijke feedback een goed hulpmiddel is rationele diagnostiek te bevorderen. Uitvoering van soortgelijke projecten binnen specialistische vakgroepen lijkt zinvol.

Wanneer er sprake is wan miet-ernstige klachten/symptomen en er wordt geen diagnose verwacht, warvoor in het kader wan onderzoek/behandeling expertise van eem subspecialist nodig is, dan kan verwijzing naar een algemeen specialist van het betreffende specialisme plaatsvinden. Wanneer de verwijzing door de huisarts niet op deze wijze gerealiseerd wordt, dan kan dit alsnog via de poliklinische triage. Via deze procedure kan voorkomen worden dat overbodige diagnostiek door de subspecialist wordt gevratagd.

\section{- Terugverwijzing: projecten chronische patienten in een stabielle fase}

Het aantal comtrolepatienten van de diverse poliklinieken blijkt in de loop der jaren toe te nemen. Bij meerdere poliklinieken bestaan problemen omtrent de wachttijden van deze controlepatiënten. Uit ervaring blijkt dat een aantal val deze patienten voor verdere controle terugverwezen zou kunnen worden naar de huisarts. Vanwege de toename vall patiënten met chronische aandoeningen, zal het duidelijk zijm dal poliklinieken door controle vam met name deze patienten 'verstopt' raken. Bekeken kan worden in hoeverre het noodzakelijk is dat deze chronische patienten in een stabiele fase door de specialist moeten worden gecontroleerd. Binnen de polikliniek interne geneeskunde/pulmonologie bestaat ar overeenstemming dat patienten met een diabetes mellitus, COPD en reuma in en stabiele fase door gespecialiseerde verpleegkundigen in de huisartsenpraktijk kunnen wordon gecontroleerd. Deze terugwerwijzing naar de huisartsenpraktijk met een centrale rol woor de gespecialiseende verpleeghondige krijgt gestalte in het project "zorgnetwerken voor chronisch zieken".

Mocht er sprake zijn van een verslechtering van het ziektebeeld dan wel complicaties, dan kan opnieuw verwijzing naar de specialist plaatsvinden. Voor het moment vindt ten aanzien van dit type patienten onderzoek plaats (diabetes mellitus, COPD en reuma). 
Ook bij andere specialismen kan worden nagegaan in howevere patièten met chronische atandoeningen aanwexig zjm die op soortgelijke wjze in de huisartsempraktik kunnert worden gecontroleerd in plaats wan in het ziekenhuis. Hierbij moet well de wolgende kanttekening worden geplatst: War woor het monent speciaal opgeleid verpleegkndigen wen anzien wan de ziektubelden diabetes mellitus, COPD en reuma werkzambeden werrichten ten behoeve van de huisartsen en specialisten, moet men zich afwragen of er bij toemame van door huisartsen te controleren chromische patienten met ook andere ziektebelden het haalbaar is verpleegkundigen per ziektiebeell te trainen. Enerzijds betekent dil dat diverse verpleegkundigen in de huisartspraktik werkaam zullen zijn, canderzijds dat bij huisartsen kennis en ervaring bij controlefbehandeling van deze ziebtebelden kunnen afremen. De vragg kan dan ook gesteld worden of het niet zinvoller is specilde verplegkundigen meer in de breedte op te leiden voor het verrichten van de huisarts ondersteumende activiteiten bij de controle van chronische patienten.

\section{- Onterecht verbliyf kliniek: AEP-protocol}

Hoewel in de loop der jaren de gemiddelde verpleegduur van patièten in de kliniek duidelijk gedaald is, kan bij kritisch wolgen van opgenomen patienten worden wastgesteld dat door incidentele en structurele problemien opnamedagen onvoldoende worden benut.

Met behulp van het Appropriateness Evaluation Protocol (AEP) kan op indexdagen bij patietiten binnen verschillende vakgroepen aan de hand van en criterialijst ragegaan worden of patienten op die dag terecht in het ziekenhuis verblijven. Als dit $\mathrm{klinische}$ wetblijif niet noodrakelijk is, kan bekeken worden of hier sprake is van een structureel probleem in de zin van bijvoorbeeld wachttijden woor speciale onderzoeken (CT-scan, endoscopie e.d.), dan wel woor te verrichten consulten e.d. Mocht dit het geval zijn, dan kan voor dergelijke structurelle problemen een oplossing wordlen gezocht, waardoor verplleegdagen kunnen worden bespaurd. Momenteel word" een bestaand AEP op onderdelen bijgesteld om voor praktisch gebruik ter beoordeling van het al dan niet noodzakelijk klinisch verblijf in het azM beter gehanteerd te kunnen worden.

In het ziekenhuis: worden regelmatig bejaarde patiënten opgenomen watrbij er meer behoefte an care dan cure bestaat. Een aantal van deze verwijzingen kan worden voorkomen als deze bejaarde patienten thuis in gezamenlijk consult huisarts-geriater worden gexien. Relatief veel bejaarde patiënten kunnen dan in een thuiszorgsetting verzorgd worden. Recent werd een project gezamenlijk consult geriatrie gestart.

\section{- Verwroegd ontsilag: diverse projecten}

Gezien de wachtlijstproblematiek in ziekenhuizen kan nagegaan worden in hoeverre het mogelijk is omschreven categorieen patiënten vervroegd te ontslaan en in een thuiszorgsetting verder te behandelen. Hierbij wordt gedacht aan patiênten die een chirurgische ingreep hebben ondergaan en waarvan nabehandeling thuis kan plaatsvinden; aan patiènten die in verband met acute problematiek opgenomen zinn en warwan nabehandeling eveneens thuis kan platsvinden, en aran patienten die medisch-technische zorg in de thuiasituatie kunnen krijgen. In azM vinden op dit terrein al enkele verbeterprojecten plats: project infuus in thuiszorg; vervroegd ontslag na totale heupprothese; wervroegd ontslag na knieprothese; de transmuralle zorgmodellen CVA en diepe veneuze trombose. Tan aunzien van andere omschreven patiöntcategoriezn kunnen soortgelijke projecten worden gepland. Overigens kan bij vervroegd ontslag van omschreven calegoriedn patienten vastgesteld worden dat er een vergrole kans is dat eet aantal patienten na vervroegd ontslag snel heropgenomen wordt. Dit gegeven zal aanleiding moeten zijn tot. verder onderzoek naar factoren die verantwoordelijk zijn voor deze snelle niet-geplande heropname. Als wia onderzoek deze factoren bekend zijn kan wervroegd ontslag meer selectief plantsvinden. 


\section{Managed care en disiense management}

Wanneer er in het kader van transmurale zorg wagen naar doeltreffende en dodmatige zorg; continuiteit van zorg, kostenbesparing ed betreffende omischreven zorgprocessen dan de orde zijn, dan worden anno 2000 methoden van managed care en disease management gebruikt om zorg met omschreven kwaliteitskenmerken te realiseren. Waar managed care gedefinieerd wordt als het raamwerk waarbinnen zorgvraag en zorgaanbod worden gestuurd op de ellementen omvang, doelmatigheid, kwaliteit en prijs, wordt onder disease management verstaan een gecoördineerde en ziektebeeld specifieke aanpak van patiêntenzorg op het operationele niweau, met als doel op de meest efficiènte wijze het best nogelijke nesultat te bereiken. Alle bij de zorgverlening betrokken partijen kunnen een rol spelen bij disease management: patiênten, huisartsen, specualisten, verpleegkundigen, apothekers, zorginstellingen, zorgverzekeraars en farmaceutische industrie. Belangen vain de verschillende partijen zullen deze rol inhoud geven. Huisartsen en specialisten zullen als direct in het primaire proces betrokkenen bijvoorbeeld aandacht besteden aan het ontwikkelen van diagnostisch- en behandelingsprotocollen, zorginstellingen zullen bij aanwezigheid van beperkte aantallen bedden in het kader van een disease managementprogramma thuiszorg met technische middelen stimuleren, terwijl zorgwerzekeraars ten aanzien van do beheersing wan kosten diverse activiteiten op het vlak van kosteneffectiviteit zullen willen beinwloeden. In aanmerking woor disease managementprogramma's komen met name ziektebeelden waarvan de prevalentie hoog is, het beloop zich uitstrekt over lange tijd, de eraan lijdende patienten als grootgebruikers van diagnostische en therapeutische hulpmiddelen gekenmerkt worden en de totale kosten van aan hen bestede zorgactiviteiten aammerkelijk zijn. Aan deze criteria voldoen ziektebeelden zoals diabetes mellitus; COPD, CVA, hart-waatziekten, hartfalen en dementie.

Wanneer op grond van genoemdle criteria een disease managementprogramma gepland wordt ten aanzien van een omschreven ziektebeeld, dan volgt er een aantal stappen in de opboun van dit programma. Begonnen wordt met een analyse van de huidige gang van zaken ten aanzien van de diverse zorgonderdelen van het primaire proces: preventie, diagnose, behandeling/zorg, nazorg en reintegratie. Op basis van de verkregen resultaten wordlen vervolgens per zorgonderdeel de doelstellingen geformuleerd waarna gestreefd wordit om het primaire proces te verbeteren. Daarna wordt aangegeven met gebruik van welke hulpmiddelen de aangegeven doelstellingen gerealiseerd moeten worden. Deze hulpmiddelen zijn van velerlei aard: registratie/informatie, communicatie/afstemming; logistiek/planning, platform/ netwerk, voorlichting/deskundigheidsbevordering, regie en financiering. Tenslotte worden concrete activiteiten per onderdeel van het primaire proces met de erbij behorende hulpmiddelen benoemd om de geformuleerde doelstellingen te realiseren.

Het zal duidelijk zijn dat disease managementprogramma's van een zelfde zjektebeeld per regio op onderdelen van elkaar kunnen werschillen, afhankelijk wan aldaar bestaande problemen/knelpunten naar voren komend uit de analyse van de huidige garg van zaken, mogelijkheden tot verbetering afhankelijk wan de aamwezigheid van hiervoor noodzakelijke hulpmiddelen en gestelde prioriteiter.

In Maastricht worden voor het moment disease managementprogramma's ontworpen voor de ziektebeelden diabetes mellitus en COPD. Bestudering van de mogelijkheden van een disease managementprogramma voom het ziektebeeld chronische vermoeidheidsyndrooni windt placts. Het betreft een ziektebeeld waarvoor in Nederland, behoudens in Nijmegen en Maastricht, nauwelijks belangstelling bestaat. Symptomatisch voon dit gebrek aan belangstelling is het gegeven dat in het kader van het reeds genoemde ZON-progtarma "verkorting doorstroomijiden" een project voor een speciale polikliniek voor chronisch vermoeide patiênten geen doorgang vond aangezien de doelgroep te valag bleek en de intermisten niet overtuigd waren wan het belang van een aparte polikliniek. 
Wanneer gekeken wordi naar problemen/knelpunten betrefferdie de zorg woor patituten met he chronische wemoeidfueidsyndroom dan lijkt in een tijd watrin gesproken wordt over doeltreffende en doelnatige zorg, voegesneden op de individuele pattent een dergelijh negatieve houding een onkening var problemen wan patienten mel dit ziektebeed. Het betreft en groep met merendeels jonge vrouwelike patienten, waarwan de grootte in Nederland op grond van in huisartspraktijken ventichte registraties geschat wondt op minimal 170.000. Door en samenloop wan factoren ontstaat er bij deze meestall tevoren actieve personen en trvaliderende moeheik met klachten in de zin van hoofdpju, duizeligheid, verminderd concentratievermogen en korl geheugen, spier-en gewnchtsklachten ed. Wameer de klachten bijwen bestain dan is wr vervolgens sprake van negatief psychische reacties zoals moedelooshid, urritaties, schuldgevoelens enz. Onwoldoende bekendheid van huisarts en specialist met dit beeld leidt vaak tot witgebreid diagnostisch onderzoek door meerdere specialisten zonder dat hierbij afwijkingen worden vastgesteld. Behandeling (dieet, witaminepreparaten, homeopathische middelen enz, vaak in het alternatieve circuir) geeft weinig of geen resultat. Negatieve reacties wan keurende artsen kunnen juridische procedures lot gevolg hebben. Een potentieel succeswolle behandeling in de zin van cognitseve gedragstherapie is a rowezig; an de mogelijkheid van deze behandeling wordt te weinig aandacht besteed. Kortom: een ziektebeeld met problemen/knelpunten in diverse aspecten van de zorg: preventie, diagnostiek; behandeling/zorg, nazorg en integratie. Een disease managementprogramma ten aanzien van patiěnten met dit ziektebeeld kan leiden tot doellmatige en doeltreffende zorg met als positieve gewolgen een besparing van hoge kosten en het vermijden van veel menselijk leed. Met nadrak wordi dit ziektebeeld natar voren gebracht aangezien tekorten aan goede zorg voor deze patienten wijst op het gevaar wan in het kader van transmurale zorg getroffen maatregelen en uitgewoerde projecten: voomang woor de ene parient ten koste van de andere patient. In de gezondheidszorg van vandaag worden veel cosmetische ingrepen verricht, aan structurele problemen wordt vaak te weinig aandacht besteed:

\section{Knelpunten ten aamaien wan ontwikkeling transmurale zorg}

Blestudering van de literatuur en ook eigen ervaringen met transmurale projecten wijzen op de aanwezigheid van belangrijke knelpunten düe een succesvolle witwoering van transmurale zorg in de weg kunnen staan. Hierbij zijn van belang:

- Een gebrekkige samenwerking en communicatie van en belangentegenstellingen tussen verschillende organisaties. Hierbij bepalen de organisaties hun strategie naar te verwachten woor- en nadelen van samenwerking en blijkt de organisatie met de meeste macht ook de meeste invloed uit te oefenen. Er bestaat onvoldoende bekendheid (mogelijkheden en beperkingen) met werkterreinen var de anderen, warvan werkeerde beeldvorming het gevolg is. Bij beroepsbeowenawen bestatat een te geringe gerichtheid op mogelijkheder wan transmurale zorg, ontbreekt vaak een geintegreerde indicatiestelling en gemeenschappelijk opgesteld zorgplan. Een onduidelijke verdeling van verantwoordelijklheden, to wensen overlatende overdracht van deskundigheden/vaandigheden en onvoldoende informatieuitwisseling tussen betrokkenen belemmeren de samenwerking. Bij inplementalie van een succesvol verlopen transmural project worden protocollen structureel ingebed binnen deelnemende instellingen on overgedragen aan aldaar functionerende managers. Structurele afstemming en zonodig bijstelling van projecten/activiteiten met managers van andere instellingen (over de muren wan de organisaties heen) vindt niet plaats.

- Beperkte deskundigheid, kennis en vaardigheden. Er is onvoldoende deskundigheid om de ventienwing zowel inhoudelijk als procesmatig worm te geven en te begelleiden. Er is sprake van beperkte kemis van medische technologie zoals infuts- en bewakingssystemen in de thuiszorg en van onvoldoende logistieke ondersteuning. 
- Gebrekkige infornatiesystemen. De kwaliteit van onderlinge informatie-uitwisseling nussen instellingen/personen werkzaam in de gezondheidszorg. lat te wensen over. Systemen zun vaak niet in staat de benodigde managenentinfomatne te leveren. Er is vaak een tekont aan dati noodzakelijk voor het verantwoord kunnen opstellen van zorgvemieuwende projecten. Naar automatiseringsplannen als het opzetten van gegevens pakhuizen waar alle instellingen en personen werkzaam in de gezondheidszorg gekoppeld worden, thient kritisch te worden gekeken. Door onzorgvuldig gebruik kumen belangen van personen en privacy wan de patiènt worden geschaad.

- Mogelijk contraproductieve acties van ziektekostenverzekeraars en famaceutische industrie. Voor ziektekostenverzekeraars, risicodragend ten aanzien wan het eerste en tweede compartiment, zal kostenbeheersing een belangrijk item zijn. Onder het noto "Wie betaalt bepaatt" zullen ziektekostenverzekeraars mogelijk mvloed willen uitoefenen op zorgwaag en zorgaambod. Uit conoumentieoverwegingen kunnen in het derde compartiment diensten/ producten worden aangeboden, wastrover principied verschill van mening bestat met zorgverleners (huisarts en specialist).

Farmaceutische bedrijven zullen vertiezen ten gevolge van Geneesmiddelenvergoedings systeem (GVS), Prijzenwet en generiek voorschrijven mogelijk trachten te compenseren door meer invloed uit te oefenen op geneesmiddelengebriik en voorschrjifgedrag. In Nederland lijkt het zelfstandig opereren op het terrein van de gezondheidszorg net door farmaceutische bedrijven ontwikkelde disease management programma's niet zinvol.

- Gebrek aan financiering. Besparingen verkregen door uitwoeridug van vernieuwende nedische activiteiten met substitutiekarakter zijn vaak onvoldoende zichtbaat te maken door de bestaande financieringsschotten. Overigens kunnen instellingen andere prioriteiten dan transmurale zorg hebben voor via substitutie vrigemaakte gelden. Ondoorzichtige regelgeving ten aanzien van de financiering van transmurale zorg, de aanwezigheid van financieringsschotten, onwil van instellingen om uitgesparde gelden de zorg te doen volgen dan wel onvermogen om zulks te doen op basis vain andere prioriteiten en het ontbreken van financiele prikkels voor het leveren van transmurale zorg, staan de witvoering hiervan nogal eens in de weg.

\section{Voorwan rden woor transmurale zorg}

Wamneer beschreven knelpunten toegespitst worden op instellingen en personen, dan kunnen oplossingen hiervoor in de zin wan voorwaarden voor een kwalitatief goede uitwoering wan transmurale zorg worden beschreven enerzijds in het algemeen, anderzijds ten aanzien van ziekenhuis, instellingen van thuiszorg, specialisten, huisartsen, ziektekostenverzekeraars, fumaceutische industrie en patiènten.

- Algemeen:

- Transmurale zorg wereist samenweiking wan hieraan hun aandeel leverende instellingen en personen. Wanneer vanuit gevoelens van onvrede met de bestande situate en op basis wan zich ontwikkelende ideeth en plannen de wil tot werandering aanwezig is, dan is hermee de erste stap op en lange weg gezet. Samenwerking van professionals en organisatio(s) binnen en over de grenzer wan disciplües, afdelingen en instellingen heen dient plaats te vinden. Zorgprocessen moeten heronworpen worden. Hieryoor zijn keninis van omschreven strategieen en methoden (Business Process Redesign, Disease Management, Integraal K waliteitsmang gement e.d. j noodzakelijk.

- Voor ontwikkeling van transmunale zorg noodzakeljike financiele middelen moeten binnen de gezondheidszorg geeamarked aanwezig zijn. Instellingen dienen varuit bestaande budgets (via herallokatie bij verplaatsing van zorg ed.) gelden hiervoo ter beschikking te stelllen. 
De overheid kan in deze een anmoedigingsbeleid voeren (inwestering in omschreven projecten, bonussen e.d.). Financiele schotten dienen, indien door de aanwezughed hierwan op omschreven platsen de ontwikkeling wan transmurale zarg belemmerd wordt, te kunnen worden onzeld door alampasing wan thestaande regelgeving.

- Ziekenhuis:

- Transmurale zorg moet een vertaling vinden in thet beleid van het ziekenhuis. Hierbij kan onderscheiden worden het strategisch beleidsplan en het medisch beleidsplan. Op basis wan discussics, watabij de diverse geledingen van het ziekenhuig betrokken zijn, dienen vanuit en omschreven visie op transmurale zorg plannen te worden ontwikkeld.

- Op organisatorisch terrein dienen mogelijkheden te worden gegewen om transmurale zorg te kunner ontwikkelen en uitvoeren. Hierbij wordt gedacht aan een Suurgroep Transmurale Zorg met vertegenwoordigers wan de diverse geledingen. Deze Stuurgroep vormt het coỏrdinatiepunt voor initiatieven transmurale zorg vit de regio, toetst woorgelegde initiativen op halbaarheid en relevantie; geeft ondersteuning aan de uitvoering van projecten en/of aan de implementate; signaleert dubbelprojecten, lecrnten, probleemsituaties op het gebied var de transmurale zorg enz. Werkgroepen voenen daadwerkelijk projecten uit. Een door de regionale gezondheidszorginstellingen gezamenlijk opgesteld beleidsplan (Regiovisie) is van belang voor de ontwikkeling van transmurale zorg.

Ir het kader wan facilitering vain transmurale activiteiten lijkt de oprichting van een Opname- en Ontglagbureau in het ziekenhuis zinvol. Via dit centrum kan sturing van opname en ontslag plaatswinden. Hierdow wordt bevorderd dat de via transmurale zorgactiviteiten vrijkomende gelden ten goede komen aan het budget voor transmurale zorg. Het Opname en Ontslagbureau kan tewens de basis zijn voor transferwerpleegkundigen en traissmuraal wetkende verpleegkundigen.

- Financiering van transmurale zorg zal ten dele door het ziekenhuis moeten plaatsvinden, aangezien hier substitutie van zorg van intra- naar extramuraal plaatsvindt. Geld dient de zorg te volgen.

Door zorgverzekenars kan gestreefd worden naar fixeren van het ziekenhuisbudget wia een aanneemsom of meerjarenafspraak. Werken met ven gegarandeerd budget maakt het mogeligk winst te halen uit doelmatig werken. Die winst kan vervolgens weer worden ingezei voor o.a. transmurale projecten. Bij aanwezigheid van een regionaal beleidsplan zal een regiobudget hiervan onderdeel uitmaken.

- Instellingen thuiszorg:

- Als er in de regio verschillende instellingen van thüszorg met een volledig pakket aan zorg werkzaam zijn, lijkt het zinvol dat deze zodlanig samenwerken, dat gezamenlijk het volledige pakket geboden wordt. Hierbij dient erop te worden toegezien, dat een verdeling van werkzaamheden op basis van goede werkafspraken plaatsvindt.

- Gezondheidszorgactiwiteiten dienen regionaal plaats te vinden op basis van werkafspraken en protocollen. Voor unifomiteit hiervan dient fe worden gezorgd, zeker wammeer in wen regio nueertere ziekenhuzen en eveneens neerdere instellingen van thuiszorg werkzam zijn. Fr dient naar te worden gestreefd, dat ziekenluizen en instellingen van thuiszorg met elkar samen werken in een op eén verhoudingen.

- In het kader vam transmurale zorg zullen speciaal getraind verpleegkundigen oen belangrijke rol spelen. Werkzaamitheden zullen zowel medisch inhoudelijk van aard zijn als op het terrein wan case-management liggen. Er is zowel behoefte aan in de diepte (per étn of enkele ziektebeelden getrainde verpleegkundigen) en meer in de breedte getrainde verpleegkundigen met medisch inhoudelijke en case-management-taken. In de huisartspraktijk gedetacheerde praktijkverpleegkundigen kunnen de huisarts ondersteunem in een diversiteit van talken. Afstemming van activiteiten van specialistisch en getteralistisch werkende verpleegkundigen en praktijkassistentes dient te worden gerealiseerd. 
- Specialisten:

- Transmurale zorg dient door specialisien gepland te wonden op het niveau van de medische staf (medisch beleidsplan) en op het nivean van vakgroepen, watr dez activiteiten plaatsvinden.

- De specialist dient in transmurale zorg als consulent aanspreekbaar te zijn. In het katier van medisch coördinerende centra kermen we verschillende vomen wan consultatie: telefonische consultatie, gezamenlijk consult in de huisartspraktijk en (gezamenlijk) consult in de thuissituatie (patienten in eindstadium enstige ziekte, chronisch bedlegerige patiènten, geriatrische patienten).

- In de honorering van de specialisten dient bet systeem van betaling naar verichting te worden afgeschaft. Afspraken over een overeengekomen volume zorg (aanneamsom) bepalen het budget. Via de interne budgettering van het ziekenhuis worden budgetten per specialisme met een zeker groeipercentage per jaar vastgesteld. Via deze procedure kan worden woorkomen dat bij ontwikkeling wan innovatieve vormen van zorg bij herhaling de vraag naar extra honorering naar voren komt.

- Huisartsen:

In het takenpakket van de huisarts wordt transmurale zorg niet genoemd. Door de Paritaire Werkgroep Huisartsenzorg wordt transmurale zorg gezien als een aanvullend aanbod, hetgeen niet van iedere huisarts individueel gevraagd zou kumen worden. Transmurale zorg is echter een demate belangrijke activiteit, dat ook de huisarts herin zijn aandeel zal moeten leveren. Ontwikkelingen in de gezondheidszorg zoals transmurale zorg houden een pleidooi in voor de verdere ontwikkeling van gezondheidscentra, waarin functiedifferentiatio van huisartsen mogelij $k$ is.

- Ziektekostenverzekeraars:

De rol van ziektekostenverzekeraars in transmurale zorg is nog niet duidelijk. In deze zullein er verschillen bestaan tussen landelijk en regional operenende verzekeraars. De lokale ziektekostenverzekeraar zal plaats nemen in de Stuurgroep Transmurale Zorg. Gedacht kan worden aan de volgende taken/functies: beheer van financien, initiérende rol bij ontwikkelingen in de zorg (vanuit kennis van diverse zorgactiviteiten in de regio), mede ontwikkelen van projecten transmurale zorg met behulp wan gegevens uil ter beschikking van dle ziektekostenverzekeraars bestaande databestanden.

- Farmacentische industrie:

Ook de rol van de farmaceutische industrie in de transmurale zorg is nog niet duidelijk. Gezien de structwur van de Nederlandse gezondheidszorg lijkt het niet opportuun dat zij zelfstandige aanbieders zijn van programma"s disease management, zoals dit in de Veranigde Staten het geval is. Via gegeven adviezen kunnen zij mede sturing geven aan de ontwikkeling van het beleid op transmuraal terrein. In het kader van activiteiten zoals voorlichting aan patiënten, nascholing van hwisartsen em specialisten kunnen zij een ro] spelen.

- Petienten..

Als de zorg afgestemd moet worden op behoente wan de patiènt, dient dit in te houden, daut sprake üs van een reele zorgvraag. Een goed voorgellichte pattient katu dan zorguragen stellen, rekening houdend met mogelijkheden en beperkingen in de zorg. Als er voor het moment nog weinig sprake is van mondige patternten die op basis vaw walide argumenten zorgvragen ed. fomuleren, dient op het terrein van de voorlichting aan patienten het een en ander nog te worden ontwikkeld. Onderscheid kan germakkt worden tussen voorlichting aan de bevolking en voorlichting aan individuele patienten. Bij voorlichting aan de bevolking kan aarsluiting gevonden worden bij het leerprogramma van de middelbare school (wiskunde: kansberekening; biologie: medisch inhoudelijke zaken; als verdere onderwerpen: veranderingen in life-style, ratio aarvullende diagnostiek, screening e.d.). Voorlichting anu de individuele patient kan meer to the point gegewen worden in groepsverband, via folders, videomateriaal e.d. Patiëntenwerenigingen kunnen bij de realisering van een en ander een bemiddelende rol spelen. 


\section{Then voorwagrden voor succes in Tranmmule zoirg}

- Gemotiveerde en deskundige betrokkenen vanuit alle deelnemende instellingen

- Aandacht woor gerichtheĩd op de patient

- Samenwerking van professionals en organisaties over grenzen van disciplines, afdelingen en instellingen theen

- Heldere anailyse wan zorgprocessen op knelpunten/problemien

- Duidelijkheid van en concensus over doelstellingen

- Heldere plamnen van aanpak, strategicën en methoden

- Voldoende bulpmiddelen en technische ondersteuning

- Voldoende menskracht en financièle middelen

- Proces- en effect-evaluaties van projecten, mede i.v.m. implementatie elders

- Voorlichting aan bevolking en aan patiënten 


\section{Literatumir}

- Assmann P, Wiernga GJ, Heman R. De eorgbrug in de regio. Een antwoond op de netpunten in de transmurale zorg. Med Contact 1998; $53: 330$.

- Beusmans $\mathrm{G}$, Velde $\mathrm{E}$ van der, Wolters $\mathrm{C}$, Boiten $\mathrm{J}$. Het transmuraal zorgmodel CVA in de regio Maastricht. Med Contact $1997 ; 42: 13147$.

- Commissie Modemisening Curatieve Zorg. Gedeelde zorg, betere zorg. Roosendaal: Koninklijke Van Poll; 1994.

- Dalen E van. Transmurale zorg, een strategische kewe...?! Een verkennend onderzoek bij ziekenhuizen en thuszorgorganisaties naar ontwikkelingen in de transmurale zorg (doctoraliscriptie). Rotterdam: Erasmus Universiteit, Instituut BMG; 1995 .

- Grinten TED van der, Hujisman R. Strategische opties voor tranismurale gezondheidszorg. Med Contact 1994; 49:1394-8.

- Grundmejier H, Weert H van. Patiënt, huisarts en internist (proefschrift). Ainsterdam: Universiteit van Amsterdam; 1992.

- Heman ER. De brug, een regionale transmurale organisatiestructuur. Researchproject MBA program. Rotterdam: School of Management; 1997.James B. Implomenting practice guidelines through clinical quality improvements. Frontiers for health serwices management $1994 ; 10: 3-37$.

- Mediator. Project verkorting van doorstroomtijden van start. Mediator 1998; 2:1-4.

- Nationale Raad voar de Volksgezondheid. Transmurale somatische zorg. Zoetarmeer; 1995.

- NTVEL. Transmurale zorg in Nederland, een inventarisatie op basis van bestande gegevensbestanden. Utrech:;1996.

- Partaire Werkgroep Huisartsenzorg. Poortwachter in praktijk. Over de platats en financiering van de huisartsenhulp in ons land. Utrecht; 1995.

- Pop P, Spreeuwenberg C. Transmurale zorg in de regio Maastricht. Van Diagnostisch Coördinerend naar Transmuraal \& Diagnostisch Centrum. Med Contact 1998; 53: $91-4$.

- Pop P, Verheggen FWSM. Verkorting van doorstroomtijden ev wachitijsten in het ziekenhuis. Selectie op structururverandering? ZM Magazine (publicatie volgt april 2000):

- Sales J, Crasborn L. Transmurale Zorg als onderneming. Een studie naar woortschrijdende inzichten in transmurale zorg (afstudeerscriptie). Katholicke Universiteit Brabant/Tilburg Institute for advanced studies; 1998.

- Schellekens WMLCM. Een passie voor patienten. Vijfde European forum on quality improvement in Health Care. Med Contact 2000; $55: 412-5$.

- Smeets, P.Pop, P. Verheggen, F. Beoordeling van de noodzaak tot ziekenhuisverblijf: de mogelijkheden van het "appropriateness evaluation protocol' nader onderzocht. Med Contact 1997:24: 757-60.

- Smeets P. Complexe medisch-technische zorg. Ontwikkeling, implementratie en evaluatie van infuus thuis (proefschrift). Maastricht: Universiteit Mastrichi; 1999.

- Spreeuwenberg C. Pop P. Transmurale zorg. In: Handboek Transmurale Zorg. Mararsen: Elsevier/Bunge; 2000 .

- Stichting Tockomstscenario's Gezondheidszorg (STGi). Managed Care en Disease Management in Nederland. Zoetemeer; 1997.

- Stichting Ziekenhwisverplatste Zorg. Ziekenhuisverplaatste zorg in het perspectief van integrale zorgsystemen (symposium). Nijmegen; 1996.

- Stuurgroep toekomstscenario's gezondheidszorg. Toekomstscenario's voor eerstelijnszorg en thuiszorg (scenariorapport). Zoetermeer; 1992.

- Transmuraal \& Diagnostisch Centrum Maastricht. Zorgwernieuwing in regionaal perspectief (symposium). Maastricht; 1997. 
- Vierhout, WPM. Het gezamenlijk consult van huisarts en specialist in de eerste lijm (proefschrift). Maastricht: Rijksuniversiteit Limburg: 1994.

- Vierhout $W$, Knotnerus $J$, Ooij $A$ van, Crebolder $H_{x}$ Pop $P$, Wesselingh-Megens $A$, Beusmans G. Effectiveness of joint consultation sessions of general practioners and orthopaedic surgeons for locomotor-system disorders. Lancet 1995; 346:990-4.

- Vlek JFM, Vierhout WPM, Pop P. Gezamenlijk consult huisarts-specialist in de huisartspraktijk. Tijdschr Huisartsgeneeskd 1997; 14:15-8.

- Voorbereidingsconmissie Invitational Conference Transmurale Zorg. Transmurale zorg quo vadis? (invitational conferenee). Utrecht; 1997.

- Winkens $\mathbf{R}$ Improving test ordening in general practice (proefschrif). Maastricht: Rijksuniversiteit Limburg, 1994 .

- Winkens R, Pop P, Buyter-Maassen A, Grol R, Kester A, Beusmans G, Knotnerus J. Randomised controlled trial of routing individual feedback to improve rationality and reduce numbers of test requests, Lancet 1995; 345: 489-502.

- Zorgverzekerars Nederland. Zorgverzekeraars en Disease Management. Zeist;1998. 